\title{
Conventions of Transcription and Orthography
}

\section{TRANSCRIPTION CONVENTIONS}

All musical examples are notated using one variant of the Central Javanese cipher notation known as the Kepatihan system. The tones of sléndro are represented by the numerals $1,2,3,5$, and 6 . The tones of pélog are represented by the numerals 1 through 7 . A period appearing in place of a numeral indicates that the previously played tone is sustained. For example, the period in the phrase 6.532 represents a continuation of the tone 6 . A period has the same durational value as a numeral. A numeral without a dot above or below it represents a tone of the central octave. A dot above the numeral indicates a tone of the high octave; a dot below, a tone of the low octave.

The notation of metrically fixed parts is end-weighted: the last notated tone of a group of tones has the most metric importance (example 1 ). Spaces between groups of notes are for legibility and do not affect the durational values of the notes.

Strokes on the structural instruments are indicated by superior letters: $\mathrm{T}$ for kethuk; P for kempul; $\mathrm{N}$ for kenong; $\mathrm{G}$ for gong. Since gong-strokes always coincide with a kenong-stroke, the former can also be written as NG. When the kenong "slips" - that is, when it plays a pitch that forecasts the future course of the melody (plèsèdan) — the $\mathrm{N}$ is followed by an arrow and an encircled numeral indicating the pitch of the kenong-stroke (example 1 ).

Each instrument or voice carries a single melodic line except for the gendèr barung, which is played with two hands, each of which typically has an independent part. The tones available in the sléndro tuning system and their distribution between the player's hands are illustrated in examples $2 \mathrm{a}$ and $2 b$. 
EXAMPLE 1. A sample balungan passage in Kepatihan cipher notation.

$$
\mathrm{N} \times(5)
$$

$\begin{array}{rr}2356 & 3532 \\ \uparrow & \uparrow\end{array}$

Points of major metric importance

EXAMPLE 2. Key to notation for the gendèr barung.

2a. Tones of a typical sléndro gendèr barung, from low to high (left to right):

range of the right-hand part

$\begin{array}{rllllllllllllll}6 & 1 & 2 & 3 & 5 & 6 & 1 & 2 & 3 & 5 & 6 & 1 & 2 & 3 \\ \end{array}$

range of the left-hand part

2b. Disposition of the hands in notation:

[notation for the right hand]

[notation for the left hand]

2c. Location of the metrical stress points:

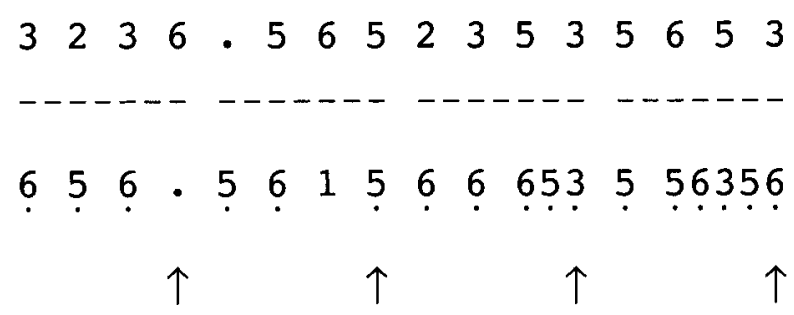


The gendèr parts notated herein are metrically bound, hence their notation is end-weighted. The broken line separating the notation of the left and right hands is divided into groups such that the rightmost beat of each group is the metrically important one.

In example $2 \mathrm{c}$ the arrows point to the metrically important beats. The rightmost arrow shows the location of the cadential tone (sèlèh) of this pattern, played by the left hand (in this case, 6).

In vocal music, texts are provided only when they are specific to a particular melody. The disposition of syllables is indicated by underscores: notes connected by underlining are sung to a single syllable.

\section{STAFF NOTATION}

After much soul-searching, I decided to include in this book trans-notations of the cipher examples in the Western staff. Since such trans-notations must be very approximate and can be misleading, I reached this decision with some reluctance. In the end, however, I decided that the potential gains outweighed the disadvantages, for the following reasons.

It has long been acknowledged that Western notation is not an ideal ethnomusicological tool. It is especially unsuited to Javanese music. The pitch materials of the gamelan cannot be represented easily on the staff; furthermore, the staff conveys a presumption of pitch standardization incompatible with the variability of Javanese intonation. In metric terms, the Western representation of downbeats as points of origin rather than points of arrival (beginnings rather than ends of metric units) is inhospitable to Javanese music as well.

Nevertheless, to shun the Western staff entirely in favor of Javanese ciphers is to fetishize notation. Notation is a communicative tool, one that like language requires a good deal of practice if its use is to become automatic and effortless. Because of the cross-cultural implications of this research, I wanted to make its results at least potentially accessible to those without Javanese musical training. Addressing such an audience in Javanese cipher notation would be as sensible as directing a speech in Javanese at monolingual Anglophone listeners. Therefore, at the risk of misrepresenting the music and annoying its adepts, I have introduced these very rough approximations. True, readers who have never heard Javanese music will not be able to use this notation to mentally construct accurate aural images of the sounds. In my defense I submit that this is an unrealistic goal; no form of notation (separated from its associated musical practices and habits) has 
table 1. Conventional Western Pitch Equivalents of the Tones of Javanese Sléndro and Pélog Used in This Book

\begin{tabular}{lccccc}
\hline & \multicolumn{3}{c}{ Sléndro } & \multicolumn{3}{c}{ Pélog } \\
\hline $\begin{array}{l}\text { Pitch } \\
\text { Name }\end{array}$ & $\begin{array}{c}\text { Cipher } \\
\text { Notation }\end{array}$ & $\begin{array}{c}\text { Western } \\
\text { Equivalent }\end{array}$ & $\begin{array}{c}\text { Pitch } \\
\text { Name }\end{array}$ & $\begin{array}{c}\text { Cipher } \\
\text { Notation }\end{array}$ & $\begin{array}{c}\text { Western } \\
\text { Equivalent }\end{array}$ \\
\hline barang & 1 & $c-$ & panunggul & 1 & $c \sharp$ \\
gulu & 2 & $d$ & gulu & 2 & $d$ \\
dhadha & 3 & $e+$ & dhadha & 3 & $e$ \\
& & & pélog & 4 & $f^{\mathbf{x}}$ \\
lima & 5 & $g$ & lima & 5 & $8^{\sharp}$ \\
nem & 6 & $a$ & nem & 6 & $a$ \\
& & & barang & 7 & $b$ \\
\hline
\end{tabular}

this power. I hope only that the staff notations will render the musical examples recognizable: I do not expect my readers to be able to sight-sing the conventional phrase type ayu kuning with perfect Javanese intonation and style, but with the aid of the staff notation I hope they can identify it when they hear it—or at least tell it apart from the phrase type puthut gelut.

I have therefore not tried to find exact Western pitch equivalents for the Javanese scales (table 1 ). For example, all of the intervals of sléndro are larger than major seconds but smaller than minor thirds. However, I have somewhat arbitrarily modified only two of the Western equivalents to pitches of the sléndro scale: thus I represent dhadha (3) as e+ and barang (I) as c-, while representing the other tones as unmodified $d, g$, and $a$. This has the unfortunate effect of making the interval between 3 and 1 look like a minor sixth, whereas the interval between 2 and 6 ( $d$ and $a$ ) looks like a perfect fifth-though in fact they are both considered to be the same interval (kempyung).

Similarly, I have not tried to reproduce the end-weighted nature of cipher notation in the staff equivalents. Metric stress is indicated as in Western music, with the downbeat of the measure falling immediately to the right of the barline. (Thus the transnotations start with a downbeat not represented in the cipher notation. I have often provided the tones that fall on this initial downbeat, even though they are not given in the cipher notation.)

In the notation of vocal music, I indicate texts only when the association of text and melodic line is fixed. Since in most cases the choice of text is left 
up to the singers, I generally indicate only the disposition of syllables by means of slurs.

\section{ORTHOGRAPHIC CONVENTIONS}

The orthography used in this study is that officially adopted by the Indonesian government since 1972, with certain added diacritical marks for Javanese. For both Javanese and Indonesian, consonants are pronounced as in English, except that $g$ is always hard, $d$ and $t$ are dentals, and $c$ is pronounced as $c h$ (e.g., "church"). $N g$ represents a velar nasal, the sound of $n$ in English "think" or of ng in "thing." In Javanese, $d h$ and th represent palatal $d$ and $t$, respectively. (Hence th sounds something like an ordinary English $t$, not the th sound in "pathetic.")

In both Javanese and Indonesian, the vowels $o, u$, and $i$ are pure ("Italian"). In Javanese, $e$ without diacritics represents a schwa (the sound of the initial and final vowels in "America"); $e$ is pronounced as the $a$ in "flame"; $\grave{e}$ is pronounced as in "bet." $A$ in Indonesian is always pure. In Javanese its sound varies according to its position: in unclosed final and penultimate syllables it is pronounced like the aw in "saw." Some writers approximate its sound by using o instead; hence we find variants like Sri Wibowo and Sri Wibawa.

Some proper names are spelled according to earlier transliteration practice, in which $j$ represents modern $y, d j$ represents $j, t j$ represents $c$, and oe represents $u$. In cases where a word appears with variant spellings (e.g., céngkok, cèngkok), I have followed W. J.S. Poerwadarminta, Baoesastra Djawa (Groningen: J. B. Wolters, 1932).

\section{IN-TEXT REFERENCES}

References to published materials follow the standard author-date system. References to interview materials are indicated by a date in the form: day (Arabic numeral), month (Roman numeral), year; for example, (24.xi.85). Since I did not usually record my interviews, most quotations from my teachers are taken from my field notes. When my teachers recounted anecdotes of their personal experiences, I have reproduced them using the thirdperson pronoun.

Sources for the musical examples are usually given in the captions. When balungan notation is not attributed, it is taken from Mloyowidodo (1976). 
This page intentionally left blank 